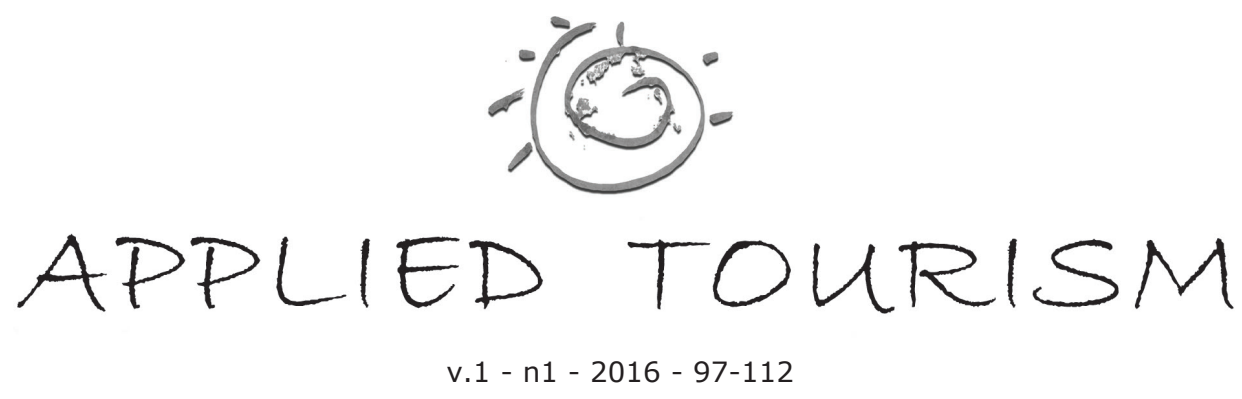

\title{
O USO DE TECNOLOGIAS EM MUSEUS E CENTROS DE VISITANTES: ESTUDO DE CASO DO CENTRO DE VISITANTES DO PROJETO TAMAR DE FERNANDO DE NORONHA - PE
}

\section{THE USE OF TECHNOLOGIES IN MUSEUMS AND VISITOR CENTERS: CASE STUDY AT THE TAMAR VISITOR CENTER IN FERNANDO DE NORONHA - PE (BRAZIL)}

\author{
Tatiane Ferrari do Vale - Mestranda em Geografia - Universidade Estadual de Ponta Grossa. \\ E-mail: tathy_ferrari@hotmail.com \\ Rafael Azevedo Robles - Especialista em Meio Ambiente, Desenvolvimento sustentável e Questões \\ Globais - Fundação Centro Brasileiro de Proteção e Pesquisa das Tartarugas Marinhas. \\ E-mail: rafael@tamar.org.br \\ Jasmine Cardozo Moreira - Doutora em Geografia - Universidade Estadual de Ponta Grossa. \\ E-mail: jasminecardozo@gmail.com
}

Recebido/Received: 10 setembro/september 2014. Aprovação/Approval: 18 janeiro/janury 2015.

Resumo: O projeto TAMAR é uma iniciativa pioneira no Brasil na conservação das tartarugas marinhas, e em 1984 se instalou em Fernando de Noronha (PE) buscando protegê-las. Com base na premissa da melhoria de serviços prestados, desenvolveuse uma pesquisa buscando conhecer a opinião dos entrevistados quanto aos aspectos da interpretação e os serviços prestados pelo Centro de Visitantes (CV) do Projeto Tamar/ ICMBio em Fernando de Noronha. Para isso, utilizou-se a pesquisa descritiva e observação in loco, e como aporte teórico a pesquisa bibliográfica. Foram entrevistados visitantes no CV e uma das principais constatações
Abstract: The Tamar Project is a Brazilian pioneering initiative for the conservation of sea turtles. It has settled in Fernando de Noronha (state of Pernambuco) in 1984, in order to protect these animals. Based on the premise of improving the services rendered, we have developed and applied a survey aiming to understand the opinion of respondents regarding the service and interpretative aspects of the services provided by the Tamar Project/ICMBio Visitor Center (VC) in Fernando de Noronha. For this purpose, we conducted a descriptive research and in loco observation, based on literature review. Visitors were interviewed in the VC 
foi a de que $80 \%$ dos entrevistados ainda preferem uma palestra tradicional a um vídeo em 3D. Com base nesse resultado, conclui-se que os turistas desejam novas tecnologias, no entanto não abrem mão da interpretação ambiental personalizada, realizada por meio das palestras. Descobrir o limite que tange o uso de tecnologias e a ausência de interpretes é um dos maiores desafios atuais dos museus e centros de visitantes.

Palavras-chave: Projeto Tamar. Fernando de Noronha. Novas Tecnologias.

\section{INTRODUÇÃO}

O Projeto Tamar tem como objetivo a pesquisa e conservação, o manejo, a sensibilização e educação ambiental e ações em prol das comunidades costeiras. Para que a pesquisa e a conservação sejam possíveis é de suma importância que as comunidades que estão inseridas nesse processo estejam envolvidas. Esse fato foi uma das características de sucesso que possibilitou que o Projeto Tamar alcançasse resultados efetivos em todo o Brasil.

Fernando de Noronha (PE) é uma das 22 bases do Projeto, que iniciou suas atividades no arquipélago em 1984. Pesquisadores do Projeto participaram das reuniões para criação do Parque Nacional Marinho de Fernando de Noronha, e com base em dados sobre as tartarugas marinhas, eles respaldaram a importância da criação dessa Unidade de Conservação.

Os anos passaram e o Projeto ganhou notoriedade nacional e internacional, estabelecendo centros de visitantes em onze de suas bases (Almofala, Fernando de Noronha, Oceanário de Aracaju, Pirambu, Praia do Forte, Arembepe, Guriri, Regência, Vitória, Ubatuba, Florianópolis). Essa iniciativa possibilita que milhares de pessoas possam conhecer esse trabalho e serem sensibilizadas por ele. Assim, o turismo surge como catalizador de recursos que beneficiam as comunidades envolvidas no Projeto e como ferramenta de sensibilização ambiental. Os visitantes, cada vez mais preocupados com questões ambientais, também estão cada vez mais exigentes, buscando novos meios de conhecimento. Portanto, melhorias, adequações e inovações são necessárias para suprir as expectativas dessa demanda.

Para evidenciar isso, foi desenvolvida uma pesquisa no Centro de Visitantes do Projeto and one of the main findings was that $80 \%$ of them still prefer a traditional talk instead of a 3D video. Based on this result, we can conclude that tourists, despite their fondness for new technologies, still appreciate personal environmental interpretation through talks. Discovering the limits concerning the use of technologies and the absence of interpreters is one of the biggest challenges of museums and visitor centers.

Keywords: Tamar Project, Fernando de Noronha, new technologies.

\section{INTRODUCTION}

The main goals of Tamar Project are research and conservation, management, awareness and environmental education and actions on behalf of coastal communities. For the research and conservation to be possible it is extremely important that the communities within this process get involved. This is one of the successful aspects which enabled the Tamar Project to reach effective results throughout Brazil.

Fernando de Noronha (state of Pernambuco) is one of the 22 bases of the Project and has started its activities in the archipelago in 1984. Researchers of the Project participated in the meetings for the creation of the Marine National Park of Fernando de Noronha and based on the data about sea turtles they endorsed the creation of this protected area (Conservation Unit, UC in the Portuguese acronym).

The years went by and the Project won national and international reputation, establishing visitor centers in 11 of its bases (Almofala, Fernando de Noronha, Oceanário de Aracaju, Pirambu, Praia do Forte, Arembepe, Guriri, Regência, Vitória, Ubatuba, Florianópolis). This initiative was an opportunity for thousands of people to contact with this work and to be touched by it. Thus, tourism arises as a catalyst of resources that benefits the communities involved with the Project and works as a tool for environmental awareness. The visitors, increasingly concerned about the environment, are also more demanding and seeking for new means of knowledge. Therefore, improvements, adjustments and innovation are necessary for meeting the expectations generated by this demand.

In order to investigate this, a survey has been conducted at the Tamar Project Visitor Center in Fernando de Noronha, addressing the environmental interpretation that has been 
Tamar em Fernando de Noronha, a qual objetivou avaliar a interpretação ambiental que vem sendo feita e conhecer quais mudanças o público deseja com relação à novas tecnologias.

Como foco desse trabalho, buscou-se conhecer as expectativas dos entrevistados quanto a inserção de novas tecnologias no Centro de Visitantes, constavam no questionário as aternativas: qr code, aplicativos para smartphone, paineis interativos, apresentações holográficas, outras tecnologias, todas e nenhuma das alternativas.

Esse artigo foi estruturado em quatro partes, a primeira busca contextualizar o arquipélago de Fernando de Noronha e o Projeto Tamar, a segunda visa explanar sobre museus e centros de visitantes, e sua aplicabilidade no Projeto Tamar de Fernando de Noronha, a terceira apresenta os resultados da pesquisa e a quarta e última parte apresenta as discussões e considerações finais.

\section{FUNDAMENTAÇÃO TEÓRICA}

Esse trabalho tem como escopo verificar por meio de uma pesquisa in loco, as expectativas dos turistas sobre os aspectos interpretativos prestados pelo Centro de Visitantes (CV) do Projeto Tamar/ICMBio em Fernando de Noronha (Pernambuco) e novas tecnologias.

As perguntas abordadas por essa pesquisa e as questões que tangem o uso de tecnologias em museus e centros de visitantes permitem uma reflexão sobre uma possível descaracterização desses locais e perda da identidade, bem como analisar os aspectos da interpretação e os serviços prestados pelo Tamar em Fernando de Noronha. Para o embasamento teórico e formulação de hipóteses foram utilizados autores como: Sabbatini (2003), Chiozinni (2004), Muchacho (2005), Pearce (2004); e conceitos de órgãos como o Conselho Internacional de Museus (ICOM) e Instituto Brasileiro de Brasileiro de Museus (IBRAM). A partir da fundação teórica, dos resultados e das discussões apresentadas podemos considerar sobre a temática em questão.

\section{ASPECTOS METODOLÓGICOS}

A metodologia utilizada para o desenvolvimento desse trabalho foi à pesquisa descritiva e observação in loco, que possibilitou o levantamento de dados acerca happening and to assess which changes the public aspires regarding the new technologies.

The aim of this work was to assess people's expectations regarding the introduction of new technologies in the Visitor Center, being the alternatives: qr code, smartphone apps, interactive panels, holographic presentations, other technologies, all and none of the alternatives.

This paper is structured in four parts: the first one contextualizes the Fernando de Noronha archipelago and the Tamar Project, the second focuses on museums and visitor centers and their applicability in Fernando de Noronha's Tamar Project base, the third shows the results of this research and the fourth presents the discussion and final considerations.

\section{THEORETICAL FRAMEWORK}

The scope of this work is to assess the tourists and locals' expectations about interpretative aspects of the services provided by the Tamar Project/ICMBio Visitor Center (VC) in Fernando de Noronha (state of Pernambuco) and new technologies.

The questions of the survey, regarding the use of new technologies in museums and visitor centers, allow a reflection about a possible loss of identity and character of these places; as well as an analysis of the interpretation aspects and the services rendered by Tamar in Fernando de Noronha. This research and formulation of hypotheses were based on the works of authors such as: Sabbatini (2003), Chiozinni (2004), Muchacho (2005), Pearce (2004); and the concepts derive from entities as the International Council of Museums (ICOM) and the Brazilian Institute of Museums (IBRAM). Based on this theoretical framework, the results and discussions presented we can comment on the topic under study.

\section{METHODOLOGICAL ASPECTS}

The methodology used was the descriptive research and in loco observation, which enabled the data collection about the profile of respondents as well as their expectations regarding the site. Moreover, the theoretical contribution of this paper was based on the literature review (e.g. books, management plans, papers, and websites).

The method used in this study can be classified as descriptive, according to 
do perfil do público entrevistado bem como suas expectativas do local, e o aporte teórico do artigo se deu pela pesquisa bibliográfica em documentos como livros, planos de manejo, artigos e websites.

Assim, a metodologia utilizada nesse artigo pode ser classificada como descritiva, pois segundo Denker (1998) "em geral procura descrever fenômenos ou estabelecer relação entre variáveis. Utiliza técnicas padronizadas de coleta de dados como o questionário e observação sistemática" (p.124). A aplicação da pesquisa descritiva se deu através de questionário elaborado com onze questões, dez fechadas e uma aberta, aplicando 100 questionários, dos quais 93 foram contabilizados.

O questionário teve como objetivo identificar o perfil dos entrevistados (sexo, idade, procedência, escolaridade), a satisfação quanto ao Centro de Visitantes do Projeto Tamar de Fernando de Noronha, o uso de novas tecnologias, a satisfação quanto às palestras interpretativas e possíveis melhorias. Adotou-se a premissa de que todos os entrevistados deveriam ter assistido ao menos uma palestra, visto que algumas questões só poderiam ser respondidas se eles tivessem tido essa experiência. Todos os questionários foram aplicados aleatoriamente, podendo os entrevistados ser turistas ou moradores. Também foi realizada a observação in loco.

\section{ARQUIPÉLAGO DE FERNANDO DE NORONHA E PROJETO TAMAR}

O arquipélago de Fernando de Noronha foi uma das primeiras terras localizadas no que historicamente foi conhecido como "novo mundo", registradas em cartas náuticas de 1500 e 1502. Sua descoberta foi atribuída ao explorador Américo Vespúcio, em 1503, sendo também uma Capitania Hereditária e um presídio político. Atualmente a Ilha é um Distrito Estadual do Estado de Pernambuco, dirigida por um administrador indicado pelo governador (Amaral, 1996).

Fernando de Noronha é formado por 21 ilhas e ilhotas, totalizando $26 \mathrm{~km}^{2}$ de extensão e 11.270 ha de área, sendo a ilha de Fernando de Noronha a principal. Localiza-se a $345 \mathrm{~km}$ a nordeste do Cabo de São Roque (RN) e 545 de Recife (PE). $O$ arquipélago é protegido por duas unidades de conservação, o Parque Nacional Marinho de Fernando de Noronha (PARNAMAR) e Área de Proteção Ambiental de Fernando de Noronha - Rocas - São Pedro e São Paulo (APA).
Denker (1998, p. 124) "in general searches to describe the phenomena or to establish the relationship between variables. It uses standard techniques of data collection as questionnaires and systematic observation". A questionnaire with 11 questions (10 closedended and one open-ended) was developed and applied to 100 people, of which 93 were analysed.

The use of the questionnaire aimed to identify the visitors' profile (gender, age, origin, level of education), assess the level of satisfaction regarding the Tamar Project Visitor Center in Fernando de Noronha, the use of new technologies, level of satisfaction regarding talks and potential improvements. We adopted the criterion that all interviewed people must have attended at least one talk, since this was a prerequisite for answering some of the questions. All questionnaires were administered randomly to tourists and locals. We also conducted an in loco observation.

\section{FERNANDO DE NORONHA ARCHIPELAGO AND TAMAR PROJECT}

The archipelago of Fernando de Noronha was one of the first pieces of land located in what is historically known as "New World", registered in nautical letters between 1500 and 1502. Its discovery was attributed to the explorer Américo Vespúcio in 1503 and it had been a Captaincy and a political prison. Nowadays, this group of islands is district of the state of Pernambuco, managed by an administrator appointed by the governor (AMARAL, 1996).

The archipelago of Fernando de Noronha consists of 21 islands and islets, a total of 26 $\mathrm{km}^{2}$ of extension and an area of $11.270 \mathrm{ha}$, and its main island is also called Fernando de Noronha. It is located $345 \mathrm{~km}$ away from the northeast of Cape São Roque (state of Rio Grande do Norte) and $545 \mathrm{~km}$ from Recife (state of Pernambuco). The archipelago is part of two conservation units, the Marine National Park of Fernando de Noronha and the Environmental Protection Area of Fernando de Noronha - Rocas - São Pedro e São Paulo.

According to CPRM (2012), the origin of the archipelago "is related to successive volcanic eruptions that occurred as a result of the movements of the South American and African tectonic plates, which give rise to the Atlantic Ocean". Fernando de Noronha "is the emerged part of a volcanic building, with a 
A origem do arquipélago de Fernando de Noronha segundo o CPRM (2012) "está relacionada a sucessivas erupções vulcânicas ocorridas devido ao movimento de placas tectônicas Sul Americana e Africana, que originaram o oceano Atlântico". Fernando de Noronha "é a parte emersa de um edifício vulcânico, cuja base com $74 \mathrm{~km}^{2}$, está assentada sobre o assoalho oceânico a cerca de $4.000 \mathrm{~m}$ de profundidade" (p.322).

0 arquipélago abriga diversidade de recursos naturais da flora e da fauna e riqueza geológica que são considerados únicos e excepcionais. A UNESCO reconheceu esse valor, e em 2001 declarou as Ilhas de Fernando de Noronha juntamente com o Atol das Rocas, Patrimônio Natural da Humanidade. Atualmente vem sendo desenvolvidas iniciativas voltadas para a inserção do arquipélago na Rede Global Geoparks (GNN) sob os auspícios da UNESCO, visto que Fernando de Noronha possui patrimônio geológico, social e cultural de importância científica, educativa e recreacional.

Em relação ao Projeto Tamar, o mesmo iniciou-se há 35 anos. Alguns estudantes de oceanografia da Universidade Federal do Rio Grande do Sul, que pesquisavam praias desertas, perceberam que ao contrário do que se pensava na época, existiam tartarugas marinhas no litoral brasileiro. Os anos passaram e o Tamar conseguiu expressivos avanços na pesquisa e conservação desses animais, fortalecendo e criando uma nova perspectiva quanto à importância de sua preservação.

A base de Fernando de Noronha desenvolve atividades de pesquisa como a Captura Intencional de Tartarugas Marinhas (Figura 1), que é primariamente de pesquisa científica e que também pode ser considerada uma prática de ecoturismo, pois permite a participação da comunidade e de turistas, visando à sensibilização quanto à importância das tartarugas marinhas. O público também pode participar do monitoramento das tartarugas em períodos de desova e aberturas públicas de ninho. O TAMAR além de se preocupar com a conservação das tartarugas marinhas valoriza a inclusão social e apoia o envolvimento das comunidades costeiras onde atua. Promove programas ambientais como o "Tamarzinhos", que estimula a participação de adolescentes, tendo por objetivo o estudo e a interação com as tartarugas marinhas (FIGURA 1 - A atividade de Captura Intencional de Tartarugas Marinhas sendo realizada na total area of $74 \mathrm{~km}^{2}$ seated on the ocean floor, $4000 \mathrm{~m}$ deep" (p. 322).

The archipelago houses diversified natural resources of flora and fauna and a geological richness that are unique and exceptional. UNESCO has recognized this value and, in 2001, declared the islands that are part of Fernando de Noronha, along with the Rocas Atoll, World Heritage Site. Currently, there are several initiatives towards its inclusion in the Global Geoparks Network (GNN) under the auspices of UNESCO, given that Fernando de Noronha possesses a geological, social and cultural heritage of scientific, educative and recreational importance.

Regarding Tamar Project, it has begun 35 years ago. Some oceanography students from the Federal University of Rio Grande do Sul who were studying deserted beaches noticed that, instead of what people thought, at that time there were sea turtles in the Brazilian coastal areas. The years went by and Tamar has achieved many expressive advances in research and conservation of these animals, generating and strengthening a new perspective in relation to their protection.

The base in Fernando de Noronha conducts research activities as the Intentional Capture of Sea Turtles (figure 1). The focus is scientific, however, it is also a practice of ecotourism, since it allows the participation of both community and tourists and aims to draw people's attention to the relevance of these animals. Furthermore, the public can also participate in the monitoring of the turtles during the nesting season and in public nest openings. Besides working towards the conservation of marine turtles, Tamar also values social inclusion and supports local coastal communities. It also promotes environmental programs as "Tamarzinhos", which stimulates the participation of teenagers in many educational and interactive activities with sea turtles (Figure 1. Intentional Capture of Sea Turtles: activity being held at Porto Beach in Fernando de Noronha (PE). Source: authors).

The 22 bases of the project are distributed across nine states of the coast of Brazil. Over the course of 35 years of work, Tamar has protected more than 20,000 nests and helped the birth of more than 15 million sea turtle hatchlings. Tamar Project aims to ensure that "old problems" as the use of these animals for food and "new problems" as marine pollution (turtles ingest the garbage in the sea) end. 
praia do Porto em Fernando de Noronha PE. Fonte: Os autores).

As 22 bases do projeto estão distribuídas em nove estados da costa brasileira, e após 35 anos de trabalho o Tamar auxiliou na proteção de mais de 20 mil ninhos e no nascimento de mais de 15 milhões de filhotes de tartarugas marinhas. O Projeto TAMAR busca cada vez mais assegurar que "velhos problemas" como a utilização desses animais para hábitos alimentares não se repitam, e "problemas atuais" como o lixo que é jogado no mar e que acaba sendo ingerido pelas tartarugas, sejam eliminados.

Para auxiliar nesse processo foram criados os Centros de Visitantes que são uma ferramenta de educação ambiental e interação, geram recursos, empregam a comunidade e tornam a experiência do turista mais satisfatória. São onze centros de visitantes distribuídos em sete estados brasileiros, sendo um deles o de Fernando de Noronha, em Pernambuco. Devido ao crescimento do turismo na década de 90 e a valorização de Fernando de Noronha como destino ecoturístico, o TAMAR decidiu instalar um centro de visitantes para integrar esse fluxo de pessoas aos programas ambientais locais (Fundação Centro Brasileiro de Proteção e Pesquisa das Tartarugas Marinhas [TAMAR], n.d).

\section{A EXPERIÊNCIA EM MUSEUS E O CASO DO MUSEU ABERTO DAS TARTARUGAS MARINHAS / CENTRO DE VISITANTES DO PROJETO TAMAR EM FERNANDO DE NORONHA - PE}

Um museu possui várias aplicabilidades, e pode ser conceituado segundo o ICOM (2013) como

uma instituição sem fins lucrativos, permanente, a serviço da sociedade e de seu desenvolvimento, aberto ao público, que adquire, conserva, comunica e exibe o patrimônio tangível e intangível da humanidade e seu ambiente para fins de educação, estudo e diversão.

Em termos gerais, os museus são locais abertos à visitação pública que exibem determinados patrimônios. Entende-se que os museus podem e devem ter funções específicas e serem classificados, visto que são dos mais diferentes temas e finalidades. Os museus de acordo com Sabbatini (2003) têm como objetivos principais,
For that purpose, Visitor Centers were created to be a tool of environmental education, generating resources, employing people from the community and turning the visit experience more pleasant for the tourists. There are 11 visitor centers distributed in seven Brazilian states, one of them being Fernando de Noronha (Pernambuco). Due to the tourism growth in the 90's and the valuation of Fernando de Noronha as an ecotourism destination, Tamar decided to establish a visitor center in order to integrate these people and the local environmental programs (Fundação Centro Brasileiro de Proteção e Pesquisa das Tartarugas Marinhas [TAMAR], n.d.).

\section{THE EXPERIENCE IN MUSEUMS AND THE CASE OF THE OPEN SEA TURTLES MUSEUM/TAMAR PROJECT VISITOR CENTER IN FERNANDO DE NORONHA - PE}

A museum has many functions and according to ICOM (2013) it can be described as a non-profit, permanent institution in the service of society and its development, open to the public, which acquires, conserves, researches, communicates and exhibits the tangible and intangible heritage of humanity and its environmental for the purposes of education, study and enjoyment.

In general terms, museums are institutions open to the public, that care for and display items of significance. There are a wide variety of museums with specific purposes, thus there are different typologies to classify them. According to Sabbatini (2003), their main goals are raise awareness of the role and importance of science in society, providing educational experiences so the users can comprehend scientific and technologic contexts and spark an interest for science and technology that will serve as encouragement for further approximations.

Sabbatini (2003) affirms that besides bringing people closer to scientific and technological advances, museums and science centers aim to "spark the interest in learning and deepen the knowledge, as well as develop critical thinking skills and provide a public space where effective decision making on the behalf of the majority can be made". Yet, the author highlights that the museum mission relates to "the ideal of scientific literacy, which is understood as the minimum level of science 
aumentar a consciência sobre o papel e a importância da ciência na sociedade, proporcionando experiências educativas para que os usuários compreendam contextos científicos e tecnológicos e despertando um interesse pela ciência e pela tecnologia que sirvam de estímulo para aproximações posteriores.

Sabbatini (2003) afirma que além da aproximação das pessoas com os avanços científicos e tecnológicos, os museus e centros de ciências entre outros objetivos visam "despertar o interesse por aprender e aprofundar conhecimentos, bem como ajudar na formação do espírito crítico e utilizar o espaço de foro do museu para a tomada de decisões eficazes em benefício da maioria." O autor ainda ressalta que a missão do museu relaciona-se "com ideal de alfabetização científica, que é entendida como o nível mínimo de compreensão em ciência e tecnologia que as pessoas precisam ter para funcionar de forma mínima como cidadãos e consumidores em nossa sociedade tecnológica".

Segundo Chiozinni (2004) o uso de novas tecnologias em museus e centros de ciência tornou-se significativo a partir da década de 1990. A partir desse contexto surgiram inúmeros museus que cada vez mais buscam aperfeiçoar seu patrimônio. Um exemplo disso é o Catavento Cultural e Educacional, em São Paulo - SP, que explora através de vários recursos tecnológicos o interesse pelas ciências.

É importante salientar que esses espaços são destinados a transmitir uma informação, que segundo Muchacho (2005), tem que se adaptar às necessidades da sociedade atual, que sofre constantes transformações. $O$ autor destaca que, "o espaço fechado em si próprio, criado com o objetivo principal de criar e salvaguardar um patrimônio, está a altera-se para transmitir um conceito e de possibilitar aos diversos públicos experiências sensíveis através da interação com o objeto museu." (Muchacho, 2005, p.579).

Assim, entende-se que os museus devem possibilitar ao público que o visita uma percepção diferenciada dos objetos que está observando, ou seja, as pessoas têm que contextualizar, interagir e sentir o museu.

Existem diferentes classificações dos museus, mas a adotada pelo Brasil é a do IBRAM (2011) que utiliza o seguinte critério: um museu pode ser de antropologia e etnografia, arqueologia, artes visuais, aplicadas, ciências naturais e história natural, and technology comprehension that people must have in order to minimally function as citizens and consumers in our technological society".

According to Chiozinni (2004) the use of new technologies in museums and science centers has become substantial in the 90 's. As a result, several museums tried to improvement in that field. A good example is the "Catavento Cultural e Educacional" in São Paulo (state of São Paulo, Brazil) that explores the interest for science through many technological resources.

It is important to underline that these spaces focus on the transmission of certain information which, according to Muchacho (2005), have to adapt to the constant changes of modern society. The author highlights that "the space closed in on itself, created with the main goal of generating and keeping a heritage, has been changing to be able to transmit a concept and give the different publics sensible experience through the interaction with the object museum" (Muchacho, 2005, p. 579).

Therefore, it is understood that museums must provide the visiting public a different perception of the objects that are being observed, i.e. people must contextualize, interact and feel the museum.

There are different classifications for museums but the definition adopted by Brazil is the one proposed by IBRAM (2011, p. 18) that uses the following criterion: a museum is a space for anthropology and ethnography, archeology, visual and applied arts, natural science and history, image and sound, virtual, bibliographical, documental and archive.

The tourists that go to museums and visitor centers are difficult to classify, unless their motivation is known. Thus, a tourist at a museum may be a cultural tourist or an ecotourist, as it depends on the theme and the real purpose of the visit.

The visitor centers are different from museums, the former focuses on the promotion of tourism and environmental interpretation. They can be defined as a tourist facility built with a different purpose and their multiple functions are important for promoting regional sustainable tourism (Pearce, 2004). The author also suggests that all visitor centers have multiple functions, such as promotion, guidance and improvement of the area's attractions, visitor's flow control and selection and replacement of visiting sites. 
ciência e tecnologia, história, imagem e som, virtual, biblioteconômico, documental e arquivístico.

O turista que se desloca a museus e centro de visitantes é dificilmente classificado, a menos que se conheça sua principal motivação de viagem. Assim, um turista que está em um museu pode ser tanto um turista cultural quanto um ecoturista, pois depende da temática do mesmo e do real interesse do turista em visitá-lo.

Os centros de visitantes se diferenciam dos museus, pois visam também a promoção do turismo e a interpretação ambiental. Eles podem ser definidos como equipamentos turísticos construídos com propósitos distintos e, suas múltiplas funções são importantes na promoção do turismo regional sustentável (Pearce, 2004). O autor ainda propõe que todos os centros de visitantes têm múltiplas funções, sendo elas a promoção, orientação e aprimoramento dos atrativos da área, controle e filtragem dos fluxos de visitantes e substituição de locais de visitas.

Os centros de visitantes são tão importantes quanto os museus, pois é por meio deles que os turistas podem obter informações sobre os atrativos turísticos locais e em alguns casos eles também apresentam o patrimônio de determinado local. É o caso de muitos parques nacionais, que além de se auto- sustentarem com a venda de produtos, possibilitam que os turistas visualizem por meios de painéis interpretativos e outras ferramentas educacionais as características ambientais e históricas dos locais.

Os centros de visitantes do Projeto Tamar, geram renda para comunidades costeiras, empregam a comunidade local e arrecadam recursos para a pesquisa e conservação das tartarugas marinhas. O Centro de Visitantes de Noronha foi inaugurado em 1996 e todas as noites apresenta palestras interpretativas relacionadas à temas ambientais. Desde a concepção do projeto arquitetônico, buscaramse alternativas ecologicamente corretas nas instalações físicas, como: madeira certificada de reflorestamento, reciclagem de containers marítimos e, estrutura instalada sobre palets removíveis para não impermeabilizar o solo.

A base do Projeto TAMAR de Fernando de Noronha, possui tanto um museu quanto um centro de visitantes. O Museu Aberto da Tartaruga Marinha é constituído pelo "espaço das tartarugas", onde podem ser encontradas réplicas das espécies que ocorrem no Brasil
The visitor centers are as important as museums, since the tourists can obtain information about the tourist attractions and, in some cases, about local heritage. This is the case of many national parks that, besides generating income from the selling of their products (self-sustaining), allow tourists to visualize aspects of the local environment and history through interpretative panels and other educational tools.

The visitor centers of Tamar Project generate income for coastal communities, create job opportunity for locals and gather resources for research and conservation of sea turtles. The visitor center in Fernando de Noronha was launched in 1996 and since then interpretative talks are given every night, always regarding environmental topics. Also the architectural project and environmentally friendly practices are implemented: certified wood of reforestation, recycling of maritime containers and removable pallets to avoid soil waterproofing.

The Tamar Project base in Fernando de Noronha consists of both a museum and a visitor center. The Open Sea Turtles Museum possesses a so called "sea turtles area", where replica of the species found in Brazil can be observed (figure 2), as well as models of nesting and panels containing information regarding the Project and the turtles. On the other hand, the visitor center encompasses the museum, the Project gift shop, an auditorium, Chelonia cafeteria (food service), outdoor amphitheater (for concerts and events) and reception stands. The Project aims to transmit knowledge by means of a clear and accessible language to all sorts of public and to all ages (Figure 2. Open Sea Turtles Museum area in Fernando de Noronha. Source: authors).

Considering that visitor centers, like museums, must be updated, we aimed to assess people's opinion through a questionnaire in order to understand what they think about the insertion of new technologies and what is their opinion regarding the Project and the resources offered by the visitor center.

\section{RESULTS}

We conducted a quanti-qualitative research with the goal of understanding what people that have visited the Tamar Project Visitor Center, in Fernando de Noronha, and have watched at least one of its talks, expect of the space and their opinion about new 
(Figura 2), bem como maquetes de desova, painéis com informações à respeito do Tamar e das tartarugas. Já o Centro de Visitantes abrange o museu, sendo composto também pela loja do projeto, auditório, Chelonia Café (área de alimentação), anfiteatro externo (local de shows e eventos), e stands de atendimento. O Projeto busca transmitir esse conhecimento por meio de uma linguagem clara e acessível a todos os tipos de público e de todas as faixas etárias (FIGURA 2 Espaço das Tartarugas do Museu Aberto de Fernando de Noronha. Fonte: Os autores).

$\mathrm{Na}$ perspectiva de que assim como os museus, os centros de visitantes também devem estar atualizados, buscou-se por meio de uma pesquisa com questionários, conhecer a opinião do público quanto à inserção de novas tecnologias, saber como eles avaliam o projeto e os recursos do centro de visitantes.

\section{RESULTADOS}

A pesquisa aplicada teve caráter quantiqualitativo, tendo como objetivo entender o que o público que frequentou o centro de visitantes do Projeto de Fernando de Noronha e assistiu ao menos uma palestra do Projeto Tamar esperava do ambiente e de novas tecnologias. Durante o $2^{\circ}$ semestre de 2013, foram aplicados 100 questionários, dos quais 93 questionarios foram contabilizados. Optou-se por aplicar essa quantidade de questionários conforme os estudos de Faria e Faria (2008), que estabelecem o número de pesquisas a serem aplicadas com base no número de visitantes. No caso do Projeto Tamar, 1500 pessoas/mês visitam o Centro de Visitantes e o Museu Aberto das Tartarugas Marinhas.

Dos 93 entrevistados, $68 \%$ são do sexo feminino e $32 \%$ do masculino. Dessas pesquisas, 92 foram respondidas por brasileiros, e apenas uma por um estrangeiro. Nota-se que o estado mais representativo dos visitantes que responderam a pesquisa foi 0 de São Paulo (28\%), seguido por Pernambuco $(22 \%)$, Rio de Janeiro $(13 \%)$ e os demais correspondentes, representam 37\%.

Dos entrevistados, a maior parte está na faixa etária entre 26 e 35 anos (41\%), seguido pela faixa-etária de 36 a 45 anos (26\%), 46 a 55 anos (14\%), 56 a 65 anos $(12 \%)$ e o restante dos participantes somam 7\%. Não houve entrevista com pessoas com menos de 18 anos e mais de 65 anos. technologies. During the second semester of 2013, 100 questionnaires were administered, of which 93 were analysed. We followed Faria and Faria (2008) for determning the amount of questionnaires to be used; according the authors the number of interviews must take into account the number of visitors. In the case of Tamar Project, there are 1,500 people/ month visiting the Visitor Center and the Open Sea Turtles Musuem.

Of 93 visitors intreviewed, $68 \%$ were female and $32 \%$ were male. We found that 92 questionnaires were answered by Brazilians and one by a foreginer. It was noted that the most representative state was São Paulo (28\%), followed by Pernambuco (22\%), Rio de Janeiro $(13 \%)$ and the others corresponded to $37 \%$.

Of the pool of interviewed people, most ages ranged between 26 and 35 years (41\%), followed by 36 to 45 years (26\%), 46 to 55 years $(14 \%), 56$ to 65 years $(12 \%)$ and the rest amounted to $7 \%$. None of the respondents were younger than 18 or older than 65 years.

Regarding their level of education, $41 \%$ of the respondents have completed undergraduate studies, other $41 \%$ are postgraduates, $10 \%$ have completed High School, $5 \%$ have not finished their undergraduate studies and the final $3 \%$ went through elementary school only.

At the visitor center, there are interpretative talks that occur every night following a prestablished schedule. We verified that the most attended talk was "Sharks", correponding to $23 \%$ of the sample, followed by "Spinner Dolphins", "Sea Turtles and the Tamar Project" (15\%), "Singing and Telling Noronha with Ju Medeiros" (12\%) and the others amounted to $29 \%$. The answers can be seen in Figure 1 (Figure 1 - Participation in Tamar Project's environmental talks. Source: authors).

Another question assessed what people thought about the talks: $78 \%$ answered "great", 22\% "good" and none answered "regular" or "bad". Moreover, people evaluated the services provided (i.e. reception and information services) as great (60\%) and good $(30 \%)$ and $10 \%$ of the respondents did not answer this question.

We also verified that $36 \%$ of the interviewees had visited other bases of the project, whilst $63 \%$ had not and the remnant $1 \%$ visited unidentified bases. The bases most cited by the visitors were: Praia do Forte state of Bahia (38\%), Ubatuba - state of São Paulo $(21 \%)$, Florianópois - state of Santa 
Com relação à escolaridade dos entrevistados, $41 \%$ das pessoas possuem o nível superior completo, e outros $41 \%$ possuem pós graduação. Dessas pessoas, $10 \%$ possuem ensino medio, $5 \%$ possuem superior incompleto e $3 \%$ possuem o ensino fundamental.

Todas as noites da semana há palestras interpretativas, que seguem uma programaçâo pré-estabelecida. Verificouse que a palestra mais assitida foi a dos Tubarões, correspondendo a 23\%, em seguida Golfinhos Rotadores, As Tartarugas Marinhas e o Projeto Tamar (15\%), Cantando e Contando Noronha com Ju Medeiros (12\%) e o restante das respostas correspondem a $29 \%$. As demais respostas podem ser oservadas no gráfico 1 (Gráfico 1 - Participação nas palestras ambientais do Projeto Tamar. Fonte: Os autores).

Perguntou-se também o que as pessoas acharam das palestras, e $78 \%$ respondeu ótimo, 22\% respondeu bom, e nenhuma respondeu regular ou ruim. Quanto aos serviços prestados, como atendimento ao público e núcleo de informações, as pessoas avaliaram $60 \%$ ótimo, 30\% bom, 10\% não responderam e nenhuma pessoa respondeu ruim.

Verificou-se também que $36 \%$ dos entrevistados visitaram outra base do projeto, enquanto que $63 \%$ não visitaram nenhuma base e $1 \%$ corresponde a bases não identificadas. Das pessoas que visitaram outras bases, as mais citadas foram: Praia do Forte (BA) $38 \%$, Ubatuba (SP) 21\%, Florianópolis (SC) $12 \%$, Pipa (RN) $7 \%$, Aracaju (SE) $5 \%$, outros $5 \%$, e $12 \%$ não responderam.

Perguntou-se às pessoas se o Centro de Visitantes do Projeto Tamar de Fernando de Noronha, havia atendido suas expectativas, e 95\% respondeu que sim, 5\% respondeu em partes e nenhuma respondeu que não. Houve também uma pergunta referente ao interresse das pessoas em participar de atividades durante o dia no centro de visitantes, como atividades teatrais, atividades infantis e oficinas, e $69 \%$ respondeu que participaria, $30 \%$ respondeu que não participaria e $1 \%$ não respondeu.

Buscando conhecer as expectativas dos entrevistados quanto a inserção de novas tecnologias no Centro de Visitantes, constavam no questionário as aternativas: $q r$ code1, aplicativos para smartphone2, paineis interativos3, apresentações holográficas4, outras tecnologias, todas e nenhuma das
Catarina (12\%), Pipa - state of Rio Grande do Norte $(7 \%)$, Aracaju - state of Sergipe (5\%). Other $5 \%$ of the respondents said "others" and $12 \%$ did not answer the question at all.

Furthermore, we asked people whether the Tamar Project Visitor Center in Fernando de Noronha had met their expectations. 95\% of them said "yes" and only 5\% answered "no". There was also a question regarding their interest to participate in the daytime activities promoted by the Visitor Center (i.e. workshops, drama or children activities). $69 \%$ answered that they would be interested on them, $30 \%$ said they would not participate and $1 \%$ did not answer.

Aiming to know the respondents' expectations regarding the insertion of new technologies in the Visitor Center, there were the following alternatives on the questionnaire: qr code1, smartphone apps2, interactive panels3, holographic presentations4, other technologies, all of them or none of them. Based on these options, we asked which one they would like the Visitor Center to adopt. Most (35\%) said they would like to see all of the options, followed by interactive panels (32\%). The rest of the answers are shown in Figure 2 (Figure 2 - Respondents preference regarding the implementation of new techonologies. Source: authors).

Regarding the interactive role of panels and expositions, $76 \%$ of the respondents said they would like it, whilst $24 \%$ did not show interest. Moreover, $80 \%$ prefer traditional talks (e.g., using slides presentation) over 3D video presentations ( $20 \%$ of respondents).

We also asked the public to rate the Tamar Project Visitor Center (in a scale of 0 to 10): $48 \%$ of the respondents gave the highest grade, $30 \%$ gave $9,18 \%$ gave $8,2 \%$ gave 7 and $2 \%$ did not answer. There were no scores below 7 .

An open-ended question assessed what people thought it could be done to improve the Visitor Center. Some of the answers were: increase the number of schedules for talks; activities for children; increase the amount of chairs in the auditorium; lightening; install a restaurant; accessibility; drinking fountains; and translation of the talks, especially into English.

\section{DISCUSSION}

While technological innovations are gaining space inside museums and visitor centers, 
alterativas. Com base nessas alternativas, perguntou-se quais eles gostariam que houvessem no Centro de Visitantes. A maioria dos entervistados (35\%) respondeu que gostaria de ver todas as tecnologias no Centro de Visitantes do Tamar, seguido dos painéis interativos (32\%). As demais respostas podem ser observadas no gráfico 2 (Gráfico 2 - Preferencia dos entrevistados quanto à novas tecnologias. Fonte: Os autores).

Quanto à interatividade dos painéis e exposições, $76 \%$ dos entrevistados respondeu que gostaria que eles fossem mais interativos, enquanto que $24 \%$ respondeu que não. Na questão sobre a preferencia das pessoas quanto a assistir uma palestra tradicional com slides e um palestrante ou um vídeo em $3 \mathrm{D}$, verificou-se que $80 \%$ prefere assitir uma palestra tradicional e $20 \%$ gostaria de ver um video em 3D.

O Centro de Visitantes do Projeto também foi avaliado com uma nota de 0 a 10 , e $48 \%$ dos entrevistados o avaliaram com nota máxima, $30 \%$ com nota $9,18 \%$ com nota 8 , $2 \%$ com nota 7 e $2 \%$ não responderam. Não houve nenhuma resposta com nota inferior a 7 .

A questão aberta indagou as pessoas sobre o que elas achavam que poderia ser melhorado no centro de visitantes, e houve respostas como: mais horários para as palestras; atividades para as crianças; aumentar a quantidade de cadeiras no auditório; iluminação; instalação de um restaurante; mais acessibilidade; bebedouros e tradução das palestras em outros idiomas, principalmente o inglês.

\section{DISCUSSÕES}

Ao mesmo tempo em que as inovações tecnológicas são cada vez mais crescentes em museus e centros de visitantes, o público ainda espera encontrar as características que conferem identidade e valor a determinados atrativos e locais. A crescente utilização de tecnologias nesses espaços permite que sejam explorados novos meios de transmitir conhecimento, mas seu uso excessivo pode descaracterizar os locais que os utilizam. A discussão sobre a intersecção do uso de tecnologias e perda da identidade é complexa e exige estudos detalhados no que se refere às características dos espaços. Muchacho (2005, p. 579) defende a ideia de que,

- museu tradicional não consegue transmitir todo o seu valor através people still wants to find those aspects that confer identity and value to certain attractions and places. The growing use of technology in these places allows new methods to be explored in order to disseminate knowledge, but its excessive use may lead to a loss of character. The discussion about the use of technology and the loss of identity is complex and requires detailed studies regarding the features of the spaces. Muchacho (2005, p. 579) defends the idea that

\begin{abstract}
the traditional museum cannot transmit all of its value through the visit, closed in itself and concerned mainly with the collection and protection of its objects, it cannot play its most rich and fundamental function: communicate with the public (p. 579).
\end{abstract}

Agreeing or not with the author would be premature, since specific studies that address the local community and tourists' opinion regarding the use of technologies and the questions related to levels of satisfaction in these spaces are needed.

This research showed that the Open Sea Turtles Museum and the Tamar Project Visitor Center in Fernando de Noronha was evaluated positively by visitors even without the use of technologies; $80 \%$ of respondents rated these spaces a 9 or a 10 . Another finding that corroborates this argument was the score of $95 \%$ of satisfaction stated by the interviewees regarding their expectations towards the visitor center.

The results showing that people prefer a traditional talk over a 3D video, confirm that the public still wish to get in touch with local community. However, it is difficult to analyze all of these questions and come out with a conclusion as at the same time that people want a traditional lecture they also want to see new technologies implemented (i.e. interactive panels, smartphone apps, gr code and holographic presentations). Moreover, our research showed that $76 \%$ of the people want the panels to be more interactive and this raises some questions: are the answers contradictory or complementary? What is the limit for using of new technologies in museums and visitor centers without erasing their identity?

The rest of the questions provided information about gender, age, origin and level of education. We verified that the majority of the respondents have completed undergraduate and post-graduate studies, 
da visita, fechado sobre si próprio e preocupado sobretudo com a coleção e salvaguarda de objetos, não consegue desempenhar a sua função mais enriquecedora e fundamental: comunicar com o público.

Concordar ou discordar com o autor seria precipitado, pois é necessário que haja estudos específicos que verifiquem a opinião da comunidade local e dos turistas quanto ao uso de tecnologias, e das questões voltadas à satisfação dessa demanda sobre esses locais.

Com essa pesquisa verificou-se que o Museu Aberto das Tartarugas Marinhas e Centro de Visitantes do Projeto Tamar de Fernando de Noronha, mesmo não utilizando tecnologias foi avaliado positivamente, considerando que quase $80 \%$ dos entrevistados deramIhe notas 9 e 10. Outra questão que ajuda a respaldar essa constatação é quanto ao atendimento das expectativas do centro de visitantes, onde $95 \%$ das pessoas afirmaram que estavam satisfeitas.

O fato de que o público ainda busca o contato com a comunidade local, pode ser confirmado pelo fato de que eles preferem assistir uma palestra com um palestrante à um vídeo em 3D. No entanto, é difícil analisar todas essas questões e chegar a uma conclusão, pois ao mesmo tempo em que as pessoas querem assistir uma palestra tradicional, elas também gostariam de ver novas tecnologias, como painéis interativos, aplicativos para smartphone, qr code $e$ apresentações holográficas. A pesquisa ainda indica que $76 \%$ das pessoas desejam que os painéis sejam mais interativos e isso faz com que nos questionemos se as respostas são contraditórias ou complementares, e qual é o limite que permite que um local utilize novas tecnologias, mas não perca sua característica.

As demais questões permitiram conhecer os dados como sexo, idade, procedência, escolaridade. Verificou-se que a maioria dos entrevistados possui pós-graduação e nível superior completo, o que nos permite supor que esse público tem maior acesso a informação, e que o mesmo pode ter inferido respostas com base em experiências préexistentes em outros museus e centros de visitantes.

Foi possível concluir também que há a necessidade de atividades durante o dia no centro de visitantes, visto que $69 \%$ das pessoas participariam se houvessem atividades teatrais, atividades infantis e oficinas. which allows us to suppose that this public may have wider access to information and that this could have resulted in answers based on pre-existent experiences at other museums and visitor centers.

We can also conclude that there is a need for daytime activities at the visitor center, since $69 \%$ of the people would participate if there were workshops, drama or children activities.

An important aspect that must be taken into account is the viability of using new technologies in the Tamar Visitor Center, since the internet connection on the island is somehow precarious; in some places the access is very slow or even inexistent. Internet downloading would be required for the use of qr codes and smartphone apps; however that could be done prior to the arrival on the island. Regarding the viability of interactive panels and the holographic presentations, financial support from Tamar Project is needed.

\section{FINAL CONSIDERATIONS}

Since its creation Tamar Project has been developing new ways of raising awareness for research and conservation of sea turtles. Before, the capture of turtles for food and a mindset resulting from the lack of laws and research were the main problems.

In such a scenario tourism has found its space, as an activity capable of generating employment opportunities and making development and conservation possible in many places. In the case of Tamar Project, the gift shops are an important source of revenue and employment for the coastal communities. The research has also found on tourism an ally, since it was through ecotourism that thousands of people have become aware of how important sea turtles are.

Regarding visitor centers, these are aimed mainly at tourists, being an important environmental tool. At Fernando de Noronha one of the most important activities of Tamar Project is the Environmental Talks Cycle; it has been happening for 17 years and provides tourists with topics of scientific and environmental relevance.

Thus, with the help of visitor centers the Project searches for new ways of improving and attracting tourists and future defenders of nature, like children. Technology is a tool that helps the process of transmitting information 
Uma questão importante a ser considerada é a viabilidade do uso dessas tecnologias no Centro de Visitantes do Tamar, pois a internet na ilha é de certa forma precária, em determinados locais o acesso é lento, ou até mesmo inexistente. O uso da internet se daria no caso do uso do qr code e dos aplicativos para smartphone, pois há necessidade de transmissão de dados para esses aparelhos telefônicos, o que poderia ser feito também antes da chegada à ilha. Com relação aos painéis interativos e as apresentações holográficas, há necessidade de recursos financeiros, por parte do Tamar, para sua viabilização.

\section{CONSIDERAÇÕES FINAIS}

O Projeto Tamar desde sua criação vem desenvolvendo novas maneiras de chamar a atenção à importância da pesquisa e conservação das tartarugas marinhas. Antes havia problemas como a captura de tartarugas para alimentação e um modo de pensar decorrente de falta de leis e pesquisas que alertassem da importância desses animais.

É nesse cenário que o turismo encontrou espaço, uma atividade capaz de gerar empregos e propiciar o desenvolvimento e a conservação de muitos lugares. No caso do Projeto Tamar, as lojas são uma importante forma de arrecadação de renda e emprego para as comunidades costeiras. A pesquisa também encontrou no turismo um aliado, pois através do ecoturismo milhares de pessoas já foram sensibilizadas sobre a importância das tartarugas marinhas.

Já os centros de visitantes são destinados principalmente aos turistas, sendo uma importante forma de sensibilização. No Projeto Tamar em Fernando de Noronha, uma das mais importantes atividades é o Ciclo de Palestras Ambientais, que acontecem há 17 anos e proporcionam ao turista contato com temas de importância cientifica e ambiental.

Dessa forma, com auxílio dos centros de visitantes, o Projeto pode buscar novas maneiras de se aperfeiçoar e atrair mais turistas e futuros defensores da natureza, como as crianças. A tecnologia é instrumento que auxilia o processo de transmissão de informação, e se exploradas adequadamente podem transmitir todo o valor de forma satisfatória. Entretanto, é fundamental que o uso de tecnologias não descaracterize os locais, mesmo que seja o desejo da demanda, pois a preservação da cultura que é agregada and, if properly explored, can disseminate the value in a satisfactory manner. Nevertheless, it is important that technologies do not wipe out the identity of the spaces, even if it is what the public desires. The protection of the culture linked to museums and visitor centers will enable future generations to get to know their characteristics.

Other related research is necessary so we can better understand to what extent we can go when it comes to the use of technologies while preserving the identity of a place. Acknowledging the importance of tourism and its sustainable and responsible development, by making use of surveys which can show clear data, will advance the scientific knowledge. Simultaneously, improvements will benefit both the community and tourists and this thin line between technological advances and loss of identity will be further apart and the knowledge will widen.

\section{REFERENCES}

Amaral, M. L. (1996). Fascínios e Mistérios do Brasil: Isso é Noronha. São Paulo: MD Comunicação e Editora.

Chiozinni, D. (2004). Museus e centros atraem crianças para uma viagem virtual ao mundo da ciência. Ciência e Cultura, 56 (2). Retrieved from http://cienciaecultura. bvs.br/scielo.ph p ? pid=S0009$67252004000200011 \&$ script $=$ sci_arttext

Dencker, A. F. M. (1998). Métodos e Técnicas de Pesquisa em Turismo. (4th ed). São Paulo: Futura.

Faria, I. S., \& Faria, M. (2008). Pesquisa de Marketing: Teoria e Prática. M Books do Brasil Editora Ltda.

Fundação Centro Brasileiro de Proteção e Pesquisa das Tartarugas Marinhas (n.d). Fernando de Noronha - PE. In Tamar Project website. Retrieved from http:// www.tamar.org.br/centros_visitantes. php?cod $=7$

Hologram. (n.d). Oxford Dictionaries. Retrieved from http://www.oxforddictionaries.com/ definition/english/hologram?q=hologram

Instituto Brasileiro de Museus. (2011). Guia Brasileiro dos Museus. Brasília: Instituto Brasileiro dos Museus.

Internacional Council of Museums. (2013). Museum Definition. In World Museum Community. Retrieved from http://icom. museum/the-vision/museum-definition/

Muchacho, R. (2005). O Museu Virtual: As Novas Tecnologias e a Reinvenção do Espaço Museológico. In Biblioteca online de 
aos museus e centros de visitantes permitirá que as futuras gerações conheçam suas características.

Outros estudos relacionados ao tema são necessários para que cada vez mais se possa avançar na compreensão de até que ponto se pode utilizar tecnologias e não descaracterizar um local. Quando se entende a importância do turismo, e esse passa a acontecer ordenadamente, utilizando-se de pesquisas que mostrem determinados resultados, o conhecimento científico estará avançando da mesma forma que as melhorias que serão implantadas estarão beneficiando a comunidade e os turistas, e essa tênue linha de avanços tecnológicos e descaracterização local estarão cada vez mais distante, e o conhecimento será mais amplo.

\section{REFERÊNCIAS}

Amaral, M. L. (1996). Fascínios e Mistérios do Brasil: Isso é Noronha. São Paulo: MD Comunicação e Editora.

Chiozinni, D. (2004, Abr./Jun). Museus e centros atraem crianças para uma viagem virtual ao mundo da ciência. Ciência e Cultura, 56 (2). Disponível em: http://cienciaecultura.bvs.br/scielo. $\mathrm{ph} p$ ? p i d = S 0009672520 $04000020000011 \& \mathrm{script}=$ sci_arttext

Dencker, A. F. M. (1998). Métodos e Técnicas de Pesquisa em Turismo. (4th ed.). São Paulo: Futura.

Faria, I. S., \& Faria, M. (2008). Pesquisa de Marketing: Teoria e Prática. M Books do Brasil Editora Ltda.

Fundação Centro Brasileiro de Proteção e Pesquisa das Tartarugas Marinhas (n.d). Fernando de Noronha - PE. In Tamar Project website. Disponível em: http:// www.tamar.org.br/centros_visitantes. php?cod $=7$

Hologram. (n.d.). Oxford Dictionaries. Disponível em: http://www. oxforddictionaries.com/definition/english/ hologram?q=hologram

Instituto Brasileiro de Museus. (2011). Guia Brasileiro dos Museus. Brasília: Instituto Brasileiro dos Museus.

Internacional Council of Museums. (n.d.). Museum Definition. In World Museum Community. Disponível em: http://icom. museum/the-vision/museum-definition/

Muchacho, R. (2005). O Museu Virtual: As Novas Tecnologias e a Reinvenção do Espaço Museológico. In Biblioteca online de ciências da comunicação. Retrieved from http://www.bocc.ubi.pt/pag/muchachorute-museu-virtual-novas-tecnologiasreinvencao-espaco-museologico.pdf

Pearce, P. L. (2004, May). The Functions and Planning of Visitors Centers in Regional Tourism. The Journal of Tourism Studies, 15, (1) 8-17. Retrieved from http:// www-public.jcu.edu.au/learningskills/idc/ groups/public/documents/journal_article/ jcudev_012876 5.pdf

Qr Code. (n.d). Oxford Dictionaries. Retrieved from http://www.oxforddictionaries.com/ definition/english/QR-code

Sabbatini, M. (2003, June). Museus e centros de ciências virtuais: Uma nova fronteira para a cultura científica. Com Ciência, (45). Retrieved from http://www.comciencia.br/ reportagens/cultura/cultura14.shtml

Wildner, W. \& Ferreira, R.V. (2012). Geoparque Fernando de Noronha (PE): Proposta. In: SHOBBENHAUS, C \& SILVA, C.R (Eds), Geoparques do Brasil: Propostas (p. 318369). Rio de Janeiro: Serviço Geológico do Brasil.

\section{NOTAS}

1 Qr Code is an optic reading code which consists of a matrix of black and white squares, generally used for URLs and other information storage that can be read by a smartphone camera (Qr Code, n.d).

2 Smartphone apps are programs and software with many functions (games, trackers) which can be installed on mobile phones.

3 Interactive panels are devices that transmit information through the use of technology and interactivity.

4 Hologram is a tridimensional image formed by the interference of a laser's light beam or other source of coherent light (Hologram, n.d) that also can be used for transmitting information through presentations in museums and visitor centers. 
ciências da comunicação. Disponível em: http://www.bocc.ubi.pt/pag/muchachorute-museu-virtual-novas-tecnologiasreinvencao-espaco-museologico.pdf

Pearce, P. L. (2004, Mai). The Functions and Planning of Visitors Centers in Regional Tourism. The Journal of Tourism Studies, 15, (1) 8-17. Disponível em: http:// www.public.jcu.edu.au/learningskills/idc/ groups/public/documents/journal_article/ jcudev_012876 5.pdf

Qr Code. (n.d.). Oxford Dictionaries. Disponível em: http://www.oxforddictionaries.com/ definition/english/QR-code

Sabbatini, M. (2003, Jul 10). Museus e centros de ciências virtuais: Uma nova fronteira para a cultura científica. Com Ciência, (45). Disponível em: http://www.comciencia.br/ reportagens/cultura/cultura14.shtml

Wildner, W. \& Ferreira, R.V. (2012). Geoparque Fernando de Noronha (PE): Proposta. In: SHOBBENHAUS, C \& SILVA, C.R (Eds), Geoparques do Brasil: Propostas (p. 318369). Rio de Janeiro: Serviço Geológico do Brasil.

\section{FOOTNOTES}

1 Qr Code é um código de leitura ótico que consiste em uma matriz de quadrados pretos e brancos, normalmente usados para armazenar URLS ou outras informações para leitura pela câmara em um smartphone (Qr Code, n.d).

2 Aplicativos para smartphone são programas e softwares com diversas finalidades (jogos, localizadores) que podem ser instalados em aparelhos celulares.

3 Painéis interativos são painéis que transmitem informações através do uso tecnológico e da interatividade.

4 Holograma é uma imagem tridimensional formada pela interferência dos feixes de luz de um lazer ou outra fonte de luz coerente (Hologram, n.d), que também podem ser usados com a finalidade de transmitir informações através de apresentações em museus e centros de visitantes. 


\section{Attachments}

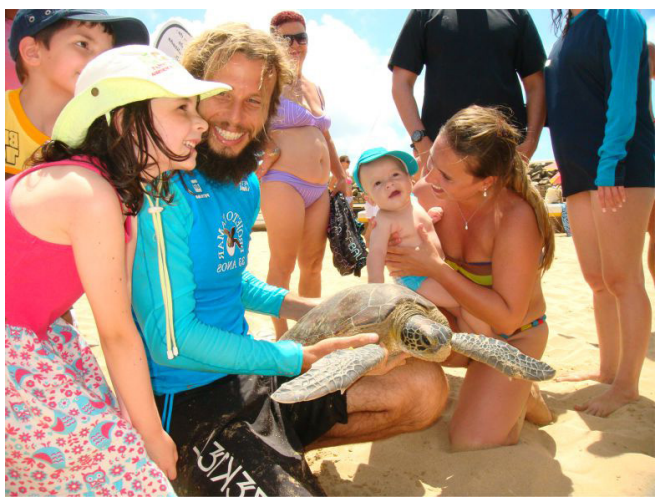

Figure 1. Intentional Capture of Sea Turtles: activity being held at Porto Beach in Fernando de Noronha (PE). Source: authors.

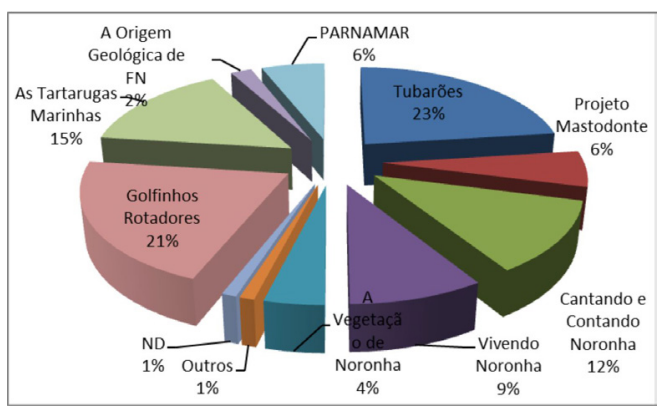

Figure 1 - Participation in Tamar Project's environmental talks. Source: authors.
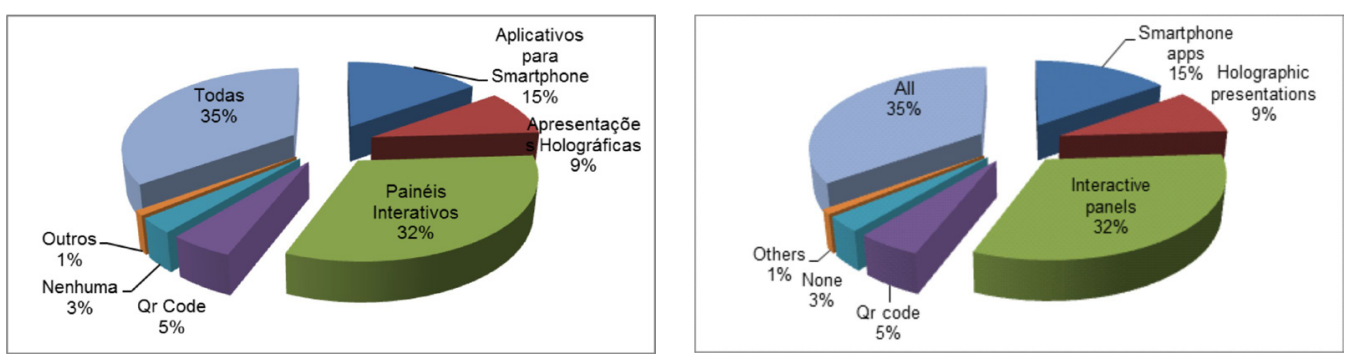

Figure 2 - Respondents preference regarding the implementation of new techonologies. Source: authors.

Figure 2. Open Sea Turtles Museum area in

Fernando de Noronha. Source: authors.
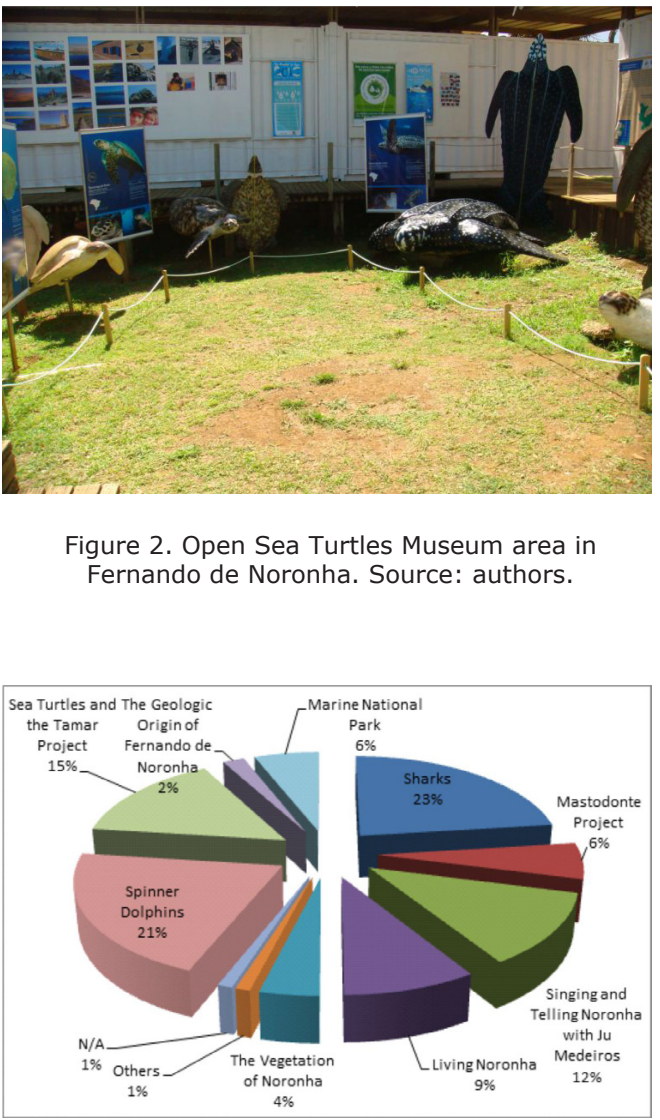